\title{
INTRODUCTION TO THE PROCEEDINGS \\ OF THE SIXTEENTH SYMPOSIUM ON BIOTECHNOLOGY FOR FUELS AND CHEMICALS
}

\author{
Brian H. Davison \\ Chemical Technology Division \\ Oak Ridge National Laboratory* \\ Oak Ridge, Tennessee 37831-6224
}



For publication in the

Proceedings of the Sixteenth Symposium on

Biotechnolgy for Fuels and Chemicals

Held at Gatlinburg, Tennessee

May 9-13, 1994

\begin{abstract}
The submitted manuscript has been authored by a contractor of the U.S. Government under contract No. DE-AC05-84OR21400. Accordingly, the U.S. Government retains a nonexclusive, royalty-free license to publish or reproduce the published form of this contribution, or allow others to do so, for U.S. Government purposes.
\end{abstract}

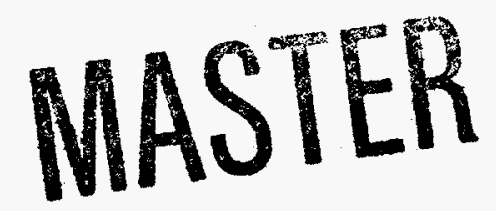

*Managed by Martin Marietta Energy Systems, Inc. for the U.S. Department of Energy under contract DE-AC05-84OR21400. 


\section{DISCLAIMER}

Portions of this document may be illegible in electronic image products. Images are produced from the best available original document. 


\title{
Introduction to the Proceedings \\ of the Sixteenth Symposium on \\ Biotechnology for Fuels and Chemicals
}

\author{
Brian H. Davison \\ Oak Ridge National Laboratory \\ Charles E. Wyman \\ National Renewable Energy Laboratory
}

Biotechnology is both an old and new technology. It has expanded from the fermentation industry to applied molecular biology.

Biotechnology can be defined as the use of biologically derived materials and biocatalysts to carry out desired transformations from one material to another. These biocatalysts can be enzymes or microorganisms. The transformation may be of raw materials into useful compounds or for the destruction of industrial wastes. One use of biotechnology is for the production of fuels and chemicals. These may be produced from renewable resources or fossil fuels.

This has been the broad area focused on by this Symposium for the past 16 years. The Symposium on Biotechnology for Fuels and Chemicals presents both applied and fundamental work in this area performed by universities, industries, and government institutions. The goal, whether near term or long term, is to find and demonstrate efficient, economical methods for the use of biotechnology to supply society's needs for fuels and chemicals. The Symposium allows interactions among the researchers in an intimate setting to foster the interactions that will be necessary to commercialize and use these technologies. Efforts presented include all aspects of the process: the pretreatment and beneficiation of the raw material, the biological conversion in some reactor, the separation and recovery of the desired product, and the treatment of the waste streams from this and earlier legacy processes. There are also efforts of the sensing, monitoring, and control of the process and well and the economic analysis to estimate the overall utility and impact.

The Sixteenth Symposium on Biotechnology for Fuels and Chemicals provided a forum for the exchange of ideas. There were 34 oral presentations and 81 poster presentations for a total of 115. These were organized into sessions of thermal, chemical, and biological processing; bioprocessing research; process economics and commercialization; and environmental biotechnology. There was also a special session on Past, Present, and Emerging Concepts in Applied Biological Research held in honor of Dr. C. D. Scott and marking the establishment of an award in his honor.

The Sixteenth Symposium was sponsored by the Biofuels Systems Division and Advanced Industrial Concepts Division of the U.S. Department of Energy (DOE); the Oak Ridge National Laboratory; National Renewable Energy Laboratory; Idaho National Engineering Laboratory; Amoco Corporation; Archer Daniels Midland Company, Bio-Technical Resources, L.P.; Dorr-Oliver Incorporated; Enzyme Bio-Systems Ltd.; Genencor International; Gist-Brocades; Golden Technologies Company, Inc.; Grain Processing Corporation; Martin Marietta Energy Systems, Inc.; Michigan Biotechnology Institute; New Energy Company of Indiana, L.P.; PSI, Process Systems, Inc.; Raphael Katzen Associates International, Inc.; Roquette America, Inc.; Solvay Enzymes, Inc.; A. E. Staley; Weyerhaeuser; and the Division of Biochemical Technology of the American Chemical Society.

Organization of the symposium was as follows: 


\section{Organizing Committee}

Jonathan Woodward, Chairman, Oak Ridge National Laboratory

Charles E. Wyman, Cochairman, National Renewable Energy Laboratory

Graham F. Andrews, Idaho National Engineering Laboratory

Antonios A. Antonopoulos, Argonne National Laboratory

Rakesh Bajpai, University of Missouri

David Boron, U.S. Department of Energy

James Doncheck, Bio-Technical Resources, L.P.

Barbara J. Goodman, National Renewable Energy Laboratory

Elias Greenbaum, Oak Ridge National Laboratory

Michael E. Himmel, National Renewable Energy Laboratory

Donald L. Johnson, Grain Processing Corporation

Raphael Katzen, Raphael Katzen Associates International, Inc.

Richard F. Moorer, U.S. Department of Energy

Mark E. Reeves, Oak Ridge National Laboratory

John N. Saddler, University of British Columbia

\section{Session Chairpersons and Cochairpersons}

Session 1: Thermal, Chemical, and Biological Processing

Bruce E. Dale, Texas A\&M University

Gene Petersen, National Renewable Energy Laboratory

Session 2: Past, Present, and Emerging Concepts in Applied Biological Research

Arthur E. Humphrey, Pennsylvania State University

Charles E. Wyman, National Renewable Energy Laboratory

Session 3: Bioprocessing Research

William A. Weigand, University of Maryland

Eric N. Kaufman, Oak Ridge National Laboratory

Session 4: Process Economics and Commercialization

Raphael Katzen, Raphael Katzen Associates International, Inc.

James Doncheck, Bio-Technical Resources, L.P.

Session 5: Environmental Biotechnology

James Petersen, Washington State University

Frederick Colwell, Idaho National Engineering Laboratory

Poster Session

Karel Grohmann, U.S. Citrus and Subtropical Products Research Laboratory

Antonios A. Antonopoulos, Argonne National Laboratory

\section{ACKNOWLEDGMENT}

The submitted manuscript has been authored by a contractor of the U.S. Government under contract DE-AC05-84OR21400. Accordingly, the U.S. Government retains a nonexclusive, royaltyfree license to publish or reproduce the published form of this contribution, or allow others to do so, for U.S. Government purposes.

Oak Ridge National Laboratory is managed by Martin Marietta Energy Systems, Inc., for the U.S. Department of Energy under contract DE-AC05-84OR21400.

The National Renewable Energy Laboratory is operated by Midwest Research Institute, for the U.S. Department of Energy under contract DE-AC02-83CH10093. 


\section{REFERENCES}

1. "Proceedings of the First Symposium on Biotechnology in Energy Production and Conservation," (1978), Biotechnol. Bioeng. Symp. 8.

2. "Proceedings of the Second Symposium on Biotechnology in Energy Production and ,Conservation," (1980), Biotechnol. Bioeng. Symp. 10.

3. "Proceedings of the Third Symposium on Biotechnology in Energy Production and Conservation," (1981), Biotechnol. Bioeng. Symp. 11.

4. "Proceedings of the Fourth Symposium on Biotechnology in Energy Production and Conservation," (1982), Biotechnol. Bioeng. Symp. 12.

5. "Proceedings of the Fifth Symposium on Biotechnology for Fuels and Chemicals," (1983), Biotechnol. Bioeng. Symp. 13.

6. "Proceedings of the Sixth Symposium on Biotechnology for Fuels and Chemicals," (1984), Biotechnol. Bioeng. Symp. 14.

7. "Proceedings of the Seventh Symposium on Biotechnology for Fuels and Chemicals," (1985), Biotechnol. Bioeng. Symp. 15.

8. "Proceedings of the Eighth Symposium on Biotechnology for Fuels and Chemicals," (1986), Biotechnol. Bioeng. Symp. 17.

9. "Proceedings of the Ninth Symposium on Biotechnology for Fuels and Chemicals," (1987), Appl. Biochem. Biotechnol. 17,18.

10. "Proceedings of the Tenth Symposium on Biotechnology for Fuels and Chemicals," (1988), Appl. Biochem. Biotechnol. 20,21.

11. "Proceedings of the Eleventh Symposium on Biotechnology for Fuels and Chemicals," (1989), Appl. Biochem. Biotechnol. 24,25.

12. "Proceedings of the Twelfth Symposium on Biotechnology for Fuels and Chemicals," (1990), Appl. Biochem. Biotechnol. 28,29.

13. "Proceedings of the Thirteenth Symposium on Biotechnology for Fuels and Chemicals," (1991), Appl. Biochem. Biotechnol. 34,35.

14. "Proceedings of the Fourteenth Symposium on Biotechnology for Fuels and Chemicals," (1992), Appl. Biochem. Biotechnol. 39,40.

15. "Proceedings of the Fifteenth Symposium on Biotechnology for Fuels and Chemicals," (1993), Appl. Biochem. Biotechnol. 45,46.

This symposium has been held annually since 1978. We are pleased to have the proceedings of the Sixteenth Symposium currently published in this special issue to continue the tradition of providing a record of the contributions made.

The Seventeenth Symposium is planned for May 7-11, 1995, in Vail, Colorado. We encourage comments or discussions relevant to the format or content of that meeting. 